\title{
ENGINEERING EDUCATION IN THE FIELD OF CIVIL ENGINEERING
}

\author{
Dr Nevenka Pavličić* \\ Faculty of Civil Engeneering, University of Montenegro, Montenegro \\ Dr Mladen Perazić \\ Montenegro Business School, Mediterranean University, Montenegro \\ Dr Dragana Đurić-Jocić \\ Faculty of Media and Communication, Singidunum University, Serbia \\ Dr Miloš Knežević \\ Faculty of Civil Engeneering, University of Montenegro, Montenegro
}

Economic growth is of a crucial importance to the prosperity of a society and its members and such growth is based on a good quality and competent labour. Educated and skilled human resources are one of the key factors to influence the positioning of a national economy in the international community. A properly regulated educational system and availability of education, as well as the "learning society" culture appear to be a generator of economic, cultural and general social progress.

Key words: Education, Engineers, Civil engineering, Human resources, Employment Agency of Montenegro

\section{INTRODUCTION}

The processes of globalisation, economic and political integrations, growth and development of multinational companies inevitably require changes to the business operations management, development of new skills and knowledge as well as the necessity to embrace the lifelong learning concept. These processes offer certain advantages such as the use of new technologies and open competition which reflects on personal development. Nevertheless, there are certain constraints in terms of unfavourable demographic and age structure of population in the European countries and Montenegro therein. A burden of legacy is seen in the inherited negative selection of human resources, transitional phenomena which requires the employees to be more adaptable, legal and institutional framework not adjusted to reflect new business practice, improper ownership transformations and socio-political impacts on the development of economy.

Faced with the challenge of growing demand for employees with the occupation-specific competencies on one side and with a limited capacity and resources available for improvement of the quality of education on the other side, the educational systems in many countries have reached a turning point. An increasing importance of knowledge and innovation for economic growth, a growing dependence on technology and an increased demand for both traditional and new skills indicate that the globalisation is not only a tool and/or instrument for production but also a requirement for a change to the education system. Researches indicate that basic skills should be enhanced to include information, communication and language competencies. According to Kulic and Despotovic, the learning society becomes a prevailing vision and ideal. It is a social evolution based on lifelong education and learning [08]. Ovesni deems that the need for longlife education has lead to differentiation among the existing and creation of new institutions, which consequently resulted in diversification in the adult education system at global level. [04]

According to P.Gazivoda, education endeavours should also continue after the school-age period so to enable distribution of knowledge and specific types of education which will be more demanded by individuals and societies. Whole life represents a continuous learning process, according to S. Milic.[09] From the aspect of economy, importance of the learning is considered in modern economic literature, with acknowledgement of the importance of higher investment in human resources. Changes in specific sectors have an 
-diate effect on the workforce demand and demand for specific type of knowledge. The changes in employment which involve higher employment in knowledge sectors and growing use of information and communication technology appear in line with development of the knowledge economy. Such changes are obvious in the developing countries, and have resulted in structural changes in the workforce demand, thus having long-term effects on the education and vocational training systems.

Construction sector has a strategic role in the development of Montenegro, yet a striking scarcity in human resources is observed in this very sector. This is proved by the fact that most of the work permits for expatriate staff have been issued for the job profiles within this sector, with the scarcity indentified at all levels of education. According to the data of the Employment Agency of Montenegro, in recent years the highest scarcity has been recorded in the supply of the following job profiles: carpenter, brick mason, steel-bender, construction equipment operator, tile slabber, insulator, geodetic technician, civil works and building construction technician, geodetic, architecture and civil engineer.

\section{ECONOMIC FUNCTION OF EDUCATION IN EUROPE}

More developed countries of EU advocate the idea of human potential being priority and key development resource, the quality of which primarily depends on adequate education and training. The quality of education and training is expected to contribute to the growth of national economy, development of human resources, sustainable national development and general well-being of individuals. For this reason, countries with market economy promote education and human resource development as a strategic objective. These countries are committed to a systemic and at national level planned development of education and training which highly benefits to economic growth, social progress and cultural development of general society as well as to the personal development of the members of society.

In the $21^{\text {st }}$ century, impact of globalisation on the society, institutions and individuals has brought to changes in the educational strategies in the more developed countries in Europe. This matter has been a subject of numerous studies and researches which are based on different viewpoints - economic, political and cultural. According to Prof D. M. Savicevic PhD, the globalisation represents a new challenge to the education and learning and any neglecting or ignoring of the globalisation phenomena would not be fruitful to the concept of scientific thinking. [02]

What is typical for the research of the European integration processes, in particular with a view to establishing and functioning of European Union, is the fact that more and more areas occur in which the EU member countries are ready to give jurisdiction to a supranational union and its institutions.[03] One of these areas refers to the issue of education. Cooperation in the field of education in EU is governed by Article 149 and Article 150, Chapter XI of the Treaty on European Union. [10] According to the mentioned articles, Member States are responsible for the content of teaching and the organisation of education systems and their cultural and linguistic diversity.

In the Lisbon Strategy [07] adopted by the European Council in 2000, EU set itself a goal to become the most competitive and dynamic knowledge-based economy in the world capable of sustainable economic growth with more and better jobs and greater social cohesion. The overall strategy is aimed at competitiveness, stimulation of research and innovations in the EU economy. The Member States are called on to prepare certain documents such as the executive program for information society as a basic method for coordinated planning and establishing of the information society. Marc Luyckx Ghisy [05] states that this decision is a business goal couched in the language of social inclusivity and sustainability. Its importance lay in its recognition that knowledge was becoming an important source of wealth. It was forward looking because instead of speaking of technologies, Europe's political leaders spoke of a knowledge society. Also crucial for the future, they also linked competitiveness and sustainability. And in pushing for social inclusion they recognised the importance of capitalising on the rising new logic of knowledge management. In a single statement, the Lisbon Summit meeting set the stage for a win-win scenario in the European Union for the first decade of the $21^{\text {st }}$ century. [06] 


\section{EDUCATION IN MONTENEGRO}

A strategic goal of the educational system in Montenegro is to provide a quality education for all individuals by reflecting the demand of the labour market and to lay sound basis for further education and vocational training. Since its start in 2000 , the implementation of the education reform has brought many changes to the structure and organisation of the educational system.

The reform has been implemented in compliance with the EU trends and demand of the economic system which is constantly changing due to the development and daily progress in science and technology. For this reason, orientation to the lifelong learning has become ever more important. The lifelong learning is aimed at perfecting of the existing knowledge and skills and acquiring new knowledge so as to facilitate transition to new technologies and improve the position of an individual in the labour market. The educational system in Montenegro consists of: 21 public and 13 private preschool education institutions, 163 primary schools, 47 secondary schools (gymnasiums, professional schools and combined schools) and one private Gymnasium, 3 resource centres, 67 licensed providers of adult education.

Education is such area that needs constant improvement taking into consideration the PISA test results of our students and employers' performance assessments, position of our universities in the world university rankings.

Results of the research performed under the project "Evaluation of the Education Reform in Montenegro", aimed at consideration and assessment of the level and quality of implementation of the reform activities in primary schools and gymnasiums are the following:

- Implementation of the reform agenda in the educational system in Montenegro proved to be necessary and resulted only in positive changes,

- Reform of the educational system in Montenegro significantly improved the quality of such system,

- A prevailing positive attitude towards the education reform is observed,

- Curriculums are effective, with all relevant learning objectives defined and knowledge standards clearly specified,

- The examinees highly ranked the quality of textbooks,
- Teachers to the large extent have competencies which are directly related to the implementation of the specific aims of the reform,

- Monitoring and improvement of the quality of education is at the satisfying level,

- Material resources needed for the achievement of the reform objectives are mostly satisfying,

- Montenegro has taken a huge step forward in the area of legal framework and education polices, created a system setting for a quality inclusive education of children with disabilities.

High quality of the educational system and vocational education as a part thereof is important both for an individual and the society. Quality vocational education represents base for an upgrade of professional knowledge, skills and competencies which are necessary for life and work of an individual. In compliance with the General Law on Education and Law on Vocational Education, the vocational education in Montenegro is provided as a lower degree vocational education in the duration of two years, middle degree vocational education lasting three or four years and higher degree vocational education lasting up to two years as post-middle degree vocational education. The vocational education also includes the craftsman's exam. The objective of the vocational education reform is to provide a more efficient response to the labour market demand. Development of qualifications is based on the performance results in all areas of work and at all levels of difficulty. It is important to ensure throughput in the educational system, to provide personal, social and professional development of any individual, and to enable comparability of the qualifications obtained in Montenegro with the qualifications obtained in other countries etc.

Considering that the investing in education of professional staff is a profitable investment and the safest path to successful business, and with an aim to reduce the discrepancy between the educational system and real demand within economy, the Governing Board of the Chamber of Commerce of Montenegro at its session held on 14 March 2013, passed a Decision on establishing the Scholarship fund for secondary professional school students educated according to the curricula for scarce occupations. The Fund is financed by those legal 
entities which state demand for the scarce qualifications and by various donors. The award of scholarships and other measures of professional orientation of students from the very beginning of the formal education process are intended to stimulate the interest of students and influence their orientation to the scarce occupations.

Enhancing cooperation between the entrepreneurs and educational institutions represents an important aspect of the improving the educational system in Montenegro.

Higher involvement of the employers in the educational system would enable better interaction and numerous advantages to either party. Taking into consideration the identified tendency of the employers towards a "ready-made staff", by provision of conditions for student practice the following interests would be satisfied: the interests of educational institutions, which would enable acquiring practical skills rather than only theoretical knowledge; the interests of pupils and students who would be prepared for efficient inclusion in the work process and the interests of the employers who would benefit from a good quality and trained staff and labour. This was one of the reasons to start with the Program of higher vocational education. The same type of program is also planned for the school students.

Comparative analyses of the European educational systems performed in the recent years have acknowledged Montenegro as an active participant in reforms, consequently in the accession process of Montenegro to the EU, Chapter 26 - Education and Culture was the first one to be temporarily closed.

\section{CIVIL ENGINEERING EDUCATIONAL QUALIFICATIONS IN MONTENEGRO}

Thirty-seven out of forty-nine secondary schools in Montenegro are professional or combined secondary schools. Within the formal educational system in Montenegro, educational qualifications for civil engineering jobs are provided indirectly in 23 professional secondary schools and directly in only 5 professional secondary schools in Podgorica, Berane, Plav, Nisic and Herceg Novi.

High education system in Montenegro comprises five faculties which provide educational for the vocation of civil engineer, these being the part of the University of Montenegro:

\section{Faculty of Civil Engineering,}

2. Faculty of Architecture,

3. Geodesy,

4. Faculty of Electrical Engineering, and

\section{Faculty of Mechanical Engineering.}

The structure of the educational process within the University in Podgorica is aligned with the modern trends in Europe. These faculties, recorded for an evident growth in number of the enrolled students, offer base and post-graduate studies in different area based on the following models:

- bachelor studies (3 years);

- postgraduate studies $(3+1)$

- master studies $(3+1+1)$

The formal educational system provides education for staff and labour for the labour market, however the problem lays in a regional scarcity and low mobility of these occupational profiles. The reason for regional scarcity and low supply of these occupational profiles in the labour market lays primarily in hard physical work, hard working conditions, low earnings, away-from-home employment, temporary employment, insufficient occupational safety. According to the data of the Employment Agency of Montenegro, almost 2/3 of the scarce labour in the construction sector refers to the III and IV degree of vocational education. The employers in central and south region of Montenegro are in need for the labour with these qualifications due to the expansion of construction works in these regions.

There are some attempts to solve the problem of scarce labour with the said educational profiles through the adult educational system, by means of retraining and additional qualifications. Non-formal education is provided by large number of the licensed instructors or those who act as NGOs and provide short non-licensed training courses. The Law on the Adult Education states that the adults can evidence the acquired knowledge, skills and competencies though sitting for exams before the Examination Centre, regardless of the manner of its acquisition. This is governed in more detail by the Law on National Vocational Qualifications.

National Education Council is responsible for the standards of knowledge that are established and verified by exams in case of evidencing the knowledge, skills and competencies, according to the educational curricula, on the basis of which or parts thereof, the publicly valid education is achieved. 
The process of regulation of the adult education system is underway. The activities are focused on networking of formal, non-formal and informal education. So far, 24 educational curricula have been adopted for the work area - construction and ge- odesy. The educational curricula for vocational training for jobs in the fileds of construction and geodesy are assigned with the Level 2 of complexity and have been approved by the Adult Education Council.

Table 1. Secondary schools - Department of Construction and Spatial Planning" - by municipalities and schools 2011/2012. Source: Ministry of Education

\begin{tabular}{|c|c|c|}
\hline Berane & Professional secondary school & Civil engineering technician \\
\hline Herceg Novi & Combined secondary school "Ivan Goran Kovacic" & Construction technician \\
\hline Niksic & The first professional secondary school & Civil engineering technician \\
\hline Plav & Combined secondary school "Beco Basic" & Architectural technician \\
\hline Podgorica & $\begin{array}{l}\text { High school of civil engineering and geodesy "Inz. } \\
\text { Marko Radevic" }\end{array}$ & Architectural technician \\
\hline Podgorica & $\begin{array}{l}\text { High school of civil engineering and geodesy "Inz. } \\
\text { Marko Radevic" }\end{array}$ & Interior designer \\
\hline Podgorica & $\begin{array}{l}\text { High school of civil engineering and geodesy "Inz. } \\
\text { Marko Radevic" }\end{array}$ & Civil engineering technician \\
\hline Podgorica & $\begin{array}{l}\text { High school of civil engineering and geodesy "Inz. } \\
\text { Marko Radevic" }\end{array}$ & Civil works technician \\
\hline Podgorica & $\begin{array}{c}\text { High school of civil engineering and geodesy "Inz. } \\
\text { Marko Radevic" }\end{array}$ & Construction technician \\
\hline Podgorica & $\begin{array}{c}\text { High school of civil engineering and geodesy "Inz. } \\
\text { Marko Radevic" }\end{array}$ & Hydro-construction technician \\
\hline Podgorica & $\begin{array}{c}\text { High school of civil engineering and geodesy "Inz. } \\
\text { Marko Radevic" }\end{array}$ & Construction installer \\
\hline Podgorica & $\begin{array}{c}\text { High school of civil engineering and geodesy "Inz. } \\
\text { Marko Radevic" }\end{array}$ & Tile slabber \\
\hline Podgorica & $\begin{array}{l}\text { High school of civil engineering and geodesy "Inz. } \\
\text { Marko Radevic" }\end{array}$ & Dry construction fitter \\
\hline
\end{tabular}

\section{CHALLENGES IN THE ENGINEER EDUCATION IN THE WORLD OF GLOBAL CHANGES}

Near future will introduce a new paradigm which assumes the competitive advantage based not only on knowledge but innovation and creativity as well. Any change to the education requires new tools for the highly qualified staff. Our students are due to accept basic concepts and principles of the market, marketing competition and managerial roles. In addition to technical skills and competencies, our civil engineers should also acquire management skills and abilities. The civil engineers should be prepared for team management along with good engineering knowledge. They are expected to operationalize their business ideas through plans.

The Faculty of Civil Engineering - University of Montenegro has acknowledge the above mentioned and consequently established a study program named "Civil Engineering and Management" taking on example of many similar schools across Europe and USA. It is intended for the staff familiar with the construction technology, legal framework, economic disciplines and busies psychology, in other words the staff for new age. In general terms, the needs of an employer contribute to the adjustment of the creative innovative ideas to the actually measured potential results.

Requirements set in our projects are always multidisciplinary - to build a hydro power plant? Yes, but the question is under which conditions. In essence, we assume high responsibility for creation of construction legacy of our lives and creation of future for the next generations. There are many pending issues that need to be solved in future. Our language is universal language of the world and our work will be appreciated by foreign audience visiting this region. 
The future times require a serious approach to the education of civil engineers that need to be considered in a long ran and based on multiple criteria. Unfortunately, at this point we have to mention that the financial situation of the University of Montenegro is rather embarrassing when compared to other European universities and requires necessary and urgent measures to provide financial sources for both teaching and research activities. Otherwise there can be no substantial changes to the education as to reflect the European standards.

Without the achieved level of quality in the field of education no proper response can be made to the time ahead us, such time imposing a need for serious approach to education. Deficiency in the energy will cause the $\mathrm{kWh}$ to become the measure of all values in the next few years. At our Faculty we have recognised this issue as well and we have started with implementation of the study program concerning energy efficiency in buildings under the scope of the postgraduate studies.

Most of the faculties of civil engineering in Europe, within their educational curricula include the studies of environmental protection with a view to the technological protection measures, aimed at preservation of eco-systems, which inevitably involves the sustainable construction.

Curricula and syllabuses need to be aligned with the most recent scientific achievements and continuously reviewed to reflect the actual state of economy.

\section{ACTIVITIES OF THE EMPLOYMENT AGENCY OF MONTENEGRO IN THE CIVIL ENGINEERING CAREERS}

Montenegro is faced with a high level of structural unemployment. The data of the Employment Agency of Montenegro indicate an evident need for adequate labour in terms of both number and quality. A scarcity is recorded in craftsmen occupation in construction, tourism and catering, agriculture and other sectors as well. The Government of Montenegro endeavors to incentivise this area by setting a legal framework, primarily the Law on Crafts, establishment of the Chamber of Crafts, passing a rulebook on the Craftsman's Exam, yet the results of the invested efforts are not as expected. Therefore, the attempts have been made to overcame the large structural mismatch between the labour supply and demand by means of various short-term training and retraining courses organised by competent and licensed adult education institutions.

Some additional education and training and retraining activties are organised in an attempt to mitigate this problem, however organisation of any comprehensive training programe requires by far larger financial resources, compliance with the regulation of the educational system and more active involvement of the Examination Center so as to provide that nationally recognised certificates do guarantee the quality of the instructor training courses. It should be highlihted that the previous experiences in practical training of the unemployed persons show that well prepared training programs or training courses have been also well accepted by the unepmployed persons and employers.

With an aim to reduce the unemployment rate, the Employment Agency of Montenegro, acting through licensed companies, organises different types of training. The analyses performed by the Employment Agency of Montenegro suggest that all atendees of training courses for known employer manage to find the employment, while $70 \%$ of trainees find their employment after completion of the training course. For the purpose of implementation of more complex training programs, regular educational institutions are also engaged.

The Employment Agency of Montenegro is highly active in the area of the adult training, through different types of retraining and additional training courses. The Law defined the Employment Agency of Montenegro as a legal person, with rights, duties and respinsabilities assigned to it in compliance with the Constitution of Montenegro, the Law and Articles of Association of the Employment Agency. The Emplyment Agency provides public serrvice with a purpose of meeting demand in the field of emplyment witthin the territory of Montenegro. The Employment Agency operates under jurisdiction of the Ministry of Labour and Social Welfare 5as well as the Republic Pension and Disabilaty Insurance Fund. [11]

Activities of the Emplyment Agency of Montenegro in this area are reflected through the following programmes:

1. Preparation for employment

2. Programmes of professional occupations training

3. Programmes for known employer

4. Programme for acquiring special knowledge 


\section{LABOUR MARKET IN MONTENEGRO}

The labour market is characterised by continuously a continuously larger labour supply than labour demand, which is evidenced by a high unemployment rate. The market is also characterised by an imbalance and mismatch in the structure of supply and demand in terms of education, qualifications or regional distribution. The labour in the labour market needs constant improvement of knowledge, additional qualifications and retraining so as to achieve higher probability of finding the employment. The market also featured by seasonal employment with high employment rate of foreign nationals which recorded a sharp drop in 2013 due to the reduced quota of work permits. In 2013 total number of announced vacancies in Montenegro was 33.328 , out of which $86,97 \%$ were temporary employments. The largest number of vacancies was announced in the accommodation and food services sector $25,68 \%$, trade $17,23 \%$ and construction $13,33 \%$.
According to the data of the Employment Agency, register of the unemployed recorded 33.980 unemployed persons as on 13 November 2013, which is $12,35 \%$ more than the year before. The unemployment rate was $14,65 \%$. The largest number of unemployed persons is recorded among those with VII (10.414), IV (9.371) and III (7.037) degree of qualifications.

Construction sector is of major significance for the economic growth of the country i particular due to its multiplicative effect on other economic activities. In the forthcoming period an increase in contribution to the national GDP is expected, especially in the period of the planned significant financial investments in capital projects and the pending highway construction project.

The construction sector engages large number of employees in Montenegro. The table below shows share of the employees working in the construction sector compared to the total number of employees.

Table: Number of employees in the sector of construction and spatial planning

\begin{tabular}{|c|c|c|c|c|c|c|c|c|c|}
\hline \multicolumn{10}{|c|}{ Number of employees in the sector of construction and spatial planning } \\
\hline \multirow{2}{*}{$\begin{array}{c}\text { Statistical Office of } \\
\text { Montenegro -Statistical } \\
\text { Yearbook of Montenegro } \\
2011 \\
\end{array}$} & \multicolumn{3}{|c|}{ Total employees } & \multicolumn{3}{|c|}{ Women } & \multicolumn{3}{|c|}{$\begin{array}{c}\% \text { women to total employ- } \\
\text { ees }\end{array}$} \\
\hline & 2008 & 2009 & 2010 & 2008 & 2009 & 2010 & 2008 & 2009 & 2010 \\
\hline Total & 166.221 & 174.152 & 161.742 & 73.469 & 77.225 & 76.757 & 44.2 & 44.3 & 47.5 \\
\hline Construction & 8831 & 9997 & 7903 & 1377 & 1367 & 1570 & 15.6 & 13.7 & 19.9 \\
\hline
\end{tabular}

\section{CONCLUSION}

In recent years development of human resources has become a subject of numerous studies, analyses ad changes across Europe. This for certain comes as consequence of the emerging information techniques and technologies, changes in labour market conditions, demand trends in the employment sector, changes in economy, social and political setting. The analysts have put an emphasis on establishment of such education and training system which will facilitate the learners to acquire those skills, knowledge and competencies that will enable them to adjust to the new labour conditions, new types of work and different working environment in a better and more flexible way.

In many European countries the change processes in education are underway or have already started. Given that formal education sys- tem is the most complex and most diversified segment of the lifelong education concept, the changes needed are also quite complex and assume different targets.

Modern tendencies of the countries with market economy indicate that education and development of human resources, with a view to new technologies, are top ranked priorities of the national strategies for socio-economic scientific and technological progress. Modern economic activities rely on highly qualified human resources who possess knowledge and skills needed to use new technologies effectively. Developed societies are committed to the creation of a "knowledge society". The effects of creativity are now more achieved through knowledge. As the effects of education do not reflect only on individuals but on the society as a whole, the knowledge is becoming a key development factor. Therefore, investing in education is another 
way to invest in human capital. It is important that not only information and science elites but total labour of one national economy acquire and apply new knowledge and information. [01]

Acknowledging the importance of the knowledge and development of human resources for economic growth and strengthening of the competitive position of Montenegro, the Montenegrin institutions, social partners and interested parties are investing joint efforts to achieve this goal. Their cooperation ad joint activities should be further enhanced as the research suggests there is still room for improvement. The knowledge based economy is not only a new paradigm, but rather a new technology which offers extraordinary results in terms of development of the country.

Which way forward to select and research? With a view to work and research activities, it would be useful to take the following steps:

1. Make an absolute and relative increase in public fund allocations for education and development of human resources as recommended at roundtables and by initiatives of the education community;

2. Reconsider total public investments as well as the investments in key segments of the education and training system and to target investments to the specific areas which need improvement, to reallocate the existing investments to the lifelong development of human resources and to form a new concept in financing of the private educational institutions;

3. Develop sectors that will deal with development of human resources and promotion of importance of the lifelong education within the existing institutional framework and economy;

4. Affirm professional orientation and counselling as one of strategic priorities in integration of education and economy.

5. Calculate long-term demand of the construction sector for education of persons for all job profiles in the overall demand planning.

6. Adjust educational curricula to match the demand of the construction sector

7. Make scholarship schemes for pupils and students as a reliable way of increasing the number of interested persons in the market of special occupations.
8. Increase activities of the retraining and training programmes

Economic growth is of a crucial importance to the prosperity of a society and its members and such growth is based on a good quality and competent labour. The educated and qualified human resources are one among key factors to influence positioning of a national economy in the international community. A properly regulated educational system and accessibility of education, as well as the "learning society" culture appear to be a generator of economic, cultural and general social progress.

\section{REFERENCES}

1) According to professor Zeljko Mrnjavac: Does Labour Disappear in the Knowledge Based Economy?

2) Dusan M. Savicevic, Comparative androgagy, Institute for Pedagogy and Andragogy, Faculty of Philosophy, University of Belgrade, Belgrade 2003, p.25

3) Gordana Ilic Gasmi, EU reforms - institutional aspects, IGP Prometej Belgrade 2004, pr. 14

4) Kristinka Ovesni, Education of Adult Educators, (European Experiences). Belgrade: Institute for Pedagogy and Andragogy, Faculty of Philosophy, University of Belgrade, Belgrade 2001, p.13

5) Marc Luyckx Ghisy PhD, mathematician, philosopher and doctor of theology, Member of World Business Academy and Dean of Cotrzgli Business Academy.

6) Marc Luyckx Ghisy, Win-Win Strategy for the European Union in the Knowledge Society, Quantum 21 net. 2007, p. 1

7) Presidency Conclusions, Lisbon European Council, 23 and 24 March 2000

8) Radivoje Kulic - Miomir Despotovic, Introduction to Andragogy, Zenica, Dom stampe 2005, p.29

9) Sasa Milic Strategy of the adult interactive learning, Actual problems of adult educaton, Scientific Symposiums, Book 82, Montenegrin Academy of Sciences and Arts 2007, p.90

10) The Treaty of Lisbon amending the Treaty on European Union and Treaty establishing the European Community 2007/C 306/01

11) www.zzzcg.org

Paper sent to revision: 07.02.2014.

Paper ready for publication: 15.03.2014. 